\title{
Review article: Medieval Irish history at the end of the twentieth century: unfinished work*
}

\begin{abstract}
A ny critique of the works of early and late twentieth-century historians of medieval Ireland cannot avoid commenting on the remarkably immutable nature of the discipline. Despite an enormous transformation in the cultural and political context in which they work, modern historians and their predecessors remain methodologically and thematically very close. The practice of medieval history in Ireland, usually epitomised by Eoin MacNeill and Goddard Henry Orpen, emerged in the early twentieth century from a fusion between many elements, among which might be considered nineteenth-century antiquarianism and romanticism, ${ }^{1}$ the groundwork of the great nineteenth-century Irish scholars (primarily Eugene O'Curry, John O'Donovan and George Petrie), the German Celtic philological school, the French school of history exemplified by L'École des Chartes, and the English historical tradition. MacNeill in his preface to Celtic Ireland $(1921)^{2}$ implied that he counted among his masters Eugene O'Curry, author of the monumental Manuscript materials of Irish history (1861), Henri d'Arbois de Jubainville and Sir John Rhys, the latter two gaining the plaudit clara et venerabilia nomina. Irish archaeology had also emerged as a fledgling discipline from a combination of orthodox and
\end{abstract}

*Early Medieval Ireland, 400-1200. By Dáibhí Ó Cróinín. Pp xvi, 379. London $\&$ New York: Longman. 1995. $£ 55$ hardback; $£ 19.99$ paperback. (Longman History of Ireland)

IRELAND AND HER NEIGHBOURS IN THE SEVENTH CENTURY. By Michael Richter. Pp 220. Dublin: Four Courts Press. 1999. IR£35.

IRELAND IN THE MIDDLE AGES. By Seán Duffy. Pp xiv, 216. London: Macmillan. 1997. $£ 20$ hardback; $£ 12.50$ paperback. (British History in Perspective); reissue, Dublin: Gill \& Macmillan. 1997. IR£13.40 paperback.

BRITAIN AND IRELAND, 900-1300: INSULAR RESPONSES TO MEDIEVAL EUROPEAN Change. Edited by Brendan Smith. Pp xv, 300. Cambridge: Cambridge University Press. 1999. £35.

IRELAND AND Britain, 1170-1450. By Robin Frame. Pp xix, 352, illus. London \& Rio Grande: Hambledon Press. 1998. £38.

ANCIENT Ireland: LIfE Before the Celts. By Laurence Flanagan. Pp viii, 272, illus. Dublin: Gill \& Macmillan. 1998. IRf16.99 hardback; IRf9.99 paperback.

${ }^{1}$ Joep Leerssen, Remembrance and imagination: patterns in the historical and literary representation of Ireland in the nineteenth century (Cork, 1996).

${ }^{2}$ Eoin MacNeill, Celtic Ireland (Dublin, 1981 ed.), pp xii-xiii. 
bizarre pursuits, among them the work of the great collectors and cataloguers associated with the Royal Irish Academy (for example, George Petrie and William Wilde) and the influence of Scandinavian and Germanic schools, particularly influenced by the Danish archaeologist J. J. A. Worsaae and the Swedish archaeologist Oscar Montelius. ${ }^{3}$ The more bizarre aspects of antiquarianism, related to masonic and other beliefs, were evident during the controversial explorations at Tara which were conducted by the BritishIsraelites from 1898 to 1903 . Archaeology and museum curatorial work began to develop at the beginning of the twentieth century under the guidance of scholars such as R. A. S. Macalister, George Coffey and T. J. Westropp, and although these scholars had not completely shunned the more bizarre aspects of their discipline, their work (like that of Petrie and Wilde) has generally stood the test of time. Celtic philology was a particularly active and productive discipline during this period, dominated by those following in the footsteps of the great Kaspar Zeuss. ${ }^{4}$ Modern scholars of all related disciplines of early and medieval Irish studies continue to be indebted to, and indeed to work in the shadows of, their nineteenth- and early twentieth-century predecessors.

This lasting influence is reflected in the parameters within which these disciplines continue to function, and also to a certain extent in the distinct reluctance to tackle the historiography of medieval Irish studies in depth. ${ }^{5}$ The parameters set down at the beginning of the twentieth century are best represented by the topics and concerns discussed by MacNeill and Orpen in their respective works: ${ }^{6}$ Celticity, Ireland and Britain in a 'Celtic' world, Ireland and the Roman Empire, the conversion of Ireland to Christianity, the political divisions of Ireland, kingship and succession in Ireland, Ireland's 'golden age', the Norse impact, the advent and impact of the Anglo-Normans, the relationship between Ireland and Britain (particularly with the English crown) in the late medieval period. It is remarkable how many of these themes resurface in the works of modern historians of medieval Ireland. While this similarity of approach is dictated by the sources and by historical events, it might also be argued that medieval Irish historians have yet to break free of parameters laid down by their predecessors and that, despite a complete change in their surroundings, have yet to gain the confidence to adopt innovative approaches to their subject. A somewhat defensive attitude pervades many medieval Irish histories, where an imagined critical audience - either at home or abroad (exemplified by

${ }^{3}$ Ole Klindt-Jensen, A history of Scandinavian archaeology (London, 1975); David Henry (ed.), Viking Ireland: Jens Worsaae's accounts of his visit to Ireland, 1846-7 (Angus, 1995).

${ }^{4} \mathrm{Kim}$ McCone, 'Prehistoric, Old and Middle Irish' in Kim McCone and Katharine Simms (eds), Progress in medieval Irish studies (Maynooth, 1996), pp 7-53.

${ }^{5}$ An exception to this reluctance is the detailed account of MacNeill's life and contribution to scholarship in F. X. Martin and F. J. Byrne (eds), The scholar revolutionary: Eoin MacNeill, 1867-1945, and the making of the new Ireland (Shannon, 1973).

${ }^{6}$ Eoin MacNeill, Phases of Irish history (Dublin, 1919); idem, Celtic Ireland (Dublin, 1921); G. H. Orpen, Ireland under the Normans, 1169-1333 (4 vols, Oxford, 1911-20), i, 5-11. 
the British/English historian) - needs to be addressed. Witness the following remarks in the introduction to Dáibhí Ó Cróinín's book:

But modern British readers could hardly be expected to concern themselves with the details of Ireland's history in the early middle ages when the Irish show no great interest in the subject themselves ... Happy to bask in the afterglow of Ireland's 'Golden Age' ... most Irish people are content that their country's early history should remain embalmed in the state in which it was left by patriotic historians of the early twentieth century ... Who would not be proud of such a history? ${ }^{7}$

Michael Richter identifies his audience in his introduction and epilogue by specifically referring to authors such as Wilhelm Levison, Edmondo Coccia and J. W. Smit, all of whose works implied that Ireland's contribution to Western Christendom in the early medieval period has been overrated. Richter's opening paragraph unambiguously proclaims the impetus driving his book:

In 1946, shortly before his death, Wilhelm Levison published his England and the Continent in the eighth century. In that widely acclaimed and influential book Ireland played an undeservedly minor part, as is clear today. In fact, the English achievements on the Continent in the eighth century which Levison investigated would have been impossible without the Irish achievements of the preceding century, in Britain as well as on the Continent. The present book [Richter's own book] is designed to make this point. ${ }^{8}$

Does this type of defensive attitude to medieval Irish history partially explain why its evidence, which is vast and wide-ranging, has not been integrated into the international narrative of medieval society. Does the excessive concern of Irish historians to protect medieval Irish history and emphasise Ireland's uniqueness and impenetrable nature ward off the greater body of scholars, or at least allow them to blame the nature of the sources for their ignorance?

A review article of this nature cannot treat each book individually in detail, nor is it in any way to be regarded as a personal criticism of any author. Too many reviews of the past century in this discipline have contained lightly veiled personal and political criticism which ultimately were to the detriment of the subject. It should be recognised that it is not easy to research a topic and to commit it cogently to writing. Equally, however, despite a marked increase in publications, there is still a dearth of quality publications in the fields of Celtic and Irish medieval studies. This inadequacy is particularly noticeable with regard to educational and popular books. Popular books and media programmes on the Celts, Celtic spirituality or Irish civilisation are generally pitifully substandard in quality and are more often than not blithely ignorant of recent scholarship." Scholars should be aware of the need to produce three categories of books: high-quality, detailed research books aimed at a professional audience,

${ }^{7}$ Ó Cróinín, Early medieval Ireland, pp xi-xii.

${ }^{8}$ Richter, Ireland \& her neighbours, p. 11.

${ }^{9}$ I acknowledge here the positive contribution made by S. J. Connolly (ed.), The Oxford companion to Irish history (Oxford, 1998) and by the quarterly publication History Ireland. 
educational handbooks for third-level students, and popular books for a general readership. Unfortunately many authors attempt to address all three audiences in one book, and by doing so fail to satisfy any of their readers. Seán Duffy's Ireland in the middle ages succeeds in this instance, as it lives up to the aim expressed on the book's cover of 'harvesting the fruits of recent research ... of interest both to experienced students of the subject and to those previously unacquainted with it'. If anyone might be disappointed, it might be the professional reader seeking an in-depth analysis. However, the book might be regarded as an introduction to others such as Brendan Smith's Britain and Ireland, 900-1300 and to Robin Frame's Ireland and Britain, 1170-1450.

In this review a common core of methodological issues and themes, which permeate throughout the works under consideration and which are relevant to the wider practice of medieval Irish history, are discussed. They may be summarised as:

Methodology

- the use of sources

- the survey versus the micro-study

- the development of an interdisciplinary approach

Themes

- traditional, stable, unique Ireland

- Ireland and Britain

- Ireland and Europe

- kingship and lordship

- possession and dispossession of land

Despite Ó Cróinín's rather agonised statement in his introduction that it is virtually impossible to write a history of early medieval Ireland because there is too much (his italics) material available to the historian of the period, an overall impression gained from the works reviewed here is that historians too often retreat to well-known sources for their evidence. Certain texts are constantly quoted, among them Patrick's Confessio and Epistola, Adomnán's Vita Columbae, Bede's Historia ecclesiastica gentis Anglorum, the Irish annals of all periods, Giraldus Cambrensis's Topographia Hiberniae and Expugnatio Hibernica, and the chanson de geste known as The song of Dermot and the earl. Notwithstanding the fact that these sources are indeed significant and that without them historians would be bereft of discerning and valuable testimonies, their constant use highlights the urgent need to edit and analyse new material. A cursory glance through the manuscript catalogues of the collections of the National Library of Ireland, the Royal Irish Academy, the Bodleian Library or the British Library testifies to the amount of manuscript material which remains either unedited or inadequately edited. For example, the concerted effort under way to make all the genealogies of medieval Ireland available (initially electronically) ${ }^{10}$ will transform our perceptions of medieval Ireland.

\footnotetext{
${ }^{11}$ These will be made available through the website CELT based in University College Cork.
} 
These genealogies are the Irish equivalent, albeit framed in a different structure, of Anglo-Saxon charters, and with the aid of computerised mapping techniques could assist scholars in plotting in considerable detail land possession and in delineating territories in medieval Ireland.

An obstacle to the use or interpretation of Irish sources is the value judgement often made when comparing one set of sources against another. The most obvious judgement arises in the post-Norman period where 'normal' sources of medieval history (charters, deeds, calendars of documents, etc.) are assessed against the 'scanty' and 'unusual' sources of late medieval Ireland. The historian's dilemma (if it is that) is best expressed by Frame when treating the relationship between the administration and the Irish in the fourteenth century:

In order to make sense of the government's activities we need to understand the nature of the enemy it faced. Unfortunately, evidence from the Gaelic side is scanty. The annals, compiled in the north and west, tend to notice south-eastern events only at moments of special drama. Almost all that can be learnt about the Irish must be gleaned from government records and from the two (excessively terse) Anglo-Irish chronicles. As a result, we tend to see the chiefs only in certain postures: rebels, suppliants and federates. The nature of life within the Irish areas and the internal politics which helped to govern their relations with the authorities remain hidden."

However, Máire Herbert offers some comfort in her essay 'Sea-divided Gaels? Constructing relationships between Irish and Scots, $c .800-1169$ ' and attempts to bridge the 'normal/abnormal' gap in that she draws not only on sources conventionally regarded as historical documentation (annals, genealogies, synchronisms of reigns) but also on other vernacular texts, "hitherto classed as "literary" and therefore largely unexploited for their historical testimony'. ${ }^{12}$ Other scholars have followed the same path in the early medieval period, less so in the later period. ${ }^{13}$ It is a treacherous path and requires a detailed knowledge of the context of each text, but it may increasingly offer the solution to the barrier described by Frame. This barrier, or mindset, of the 'normal' and 'abnormal' that accompanies it unfortunately continues to exacerbate cultural or ethnic differences, to deny the complexity of cross-cultural contacts, and probably causes statements such as that made by John Gillingham in his essay 'Killing and mutilating political enemies in the British Isles from the late twelfth to the early fourteenth century: a comparative study' (despite the author's genuine attempts to diffuse existing prejudices):

If Wales and Scotland joined the European club [regarding new rules of political conflict], however, Ireland did not. Traditional patterns of violence continued unabated throughout the thirteenth century and beyond. Irish blood continued to be spilt both by the English and by the Irish themselves. ${ }^{14}$

${ }^{11}$ Frame, Ireland \& Britain, p. 251.

${ }^{12}$ Smith (ed.), Britain \& Ireland, pp 87-8.

${ }^{13}$ Aoife Nic Ghiollamhaith, 'Kings and vassals in later medieval Ireland: the Uí Bhriain and the MicConmara in the fourteenth century' in T. B. Barry, Robin Frame and Katharine Simms (eds), Colony and frontier in medieval Ireland: essays presented to J. F. Lydon (London \& Rio Grande, 1995), pp 201-16.

${ }^{14}$ Smith (ed.), Britain \& Ireland, p. 125. 
Frame's cautionary observations regarding H. S. Sweetman's Calendar of documents relating to Ireland, $1171-1307$ (1875-86) ${ }^{15}$ should remind historians of the pitfalls in using existing editions and of the absolute necessity, as suggested by Herbert, to explore the total context of a text or document. Interpretations of texts, particularly of the early medieval period, can also be skewed by views as to the date, as evidenced, for example, by Richter's acceptance that Amra Coluim Cille, composed to lament the death of Columba, 'was completed very soon after Colum Cille's death'. ${ }^{16}$ This is a complex text which, lacking an adequate modern edition, has yet to be definitively dated as early as c. 600. Similarly, assumed lacunae in the sources and the ensuing difficulties can hinder further advances in relation to a topic. Ó Cróinín's belief concerning the sources for Munster and Connacht before A.D. 800 exemplifies self-imposed barriers: 'If the sources for the early history of Munster are meagre, those for Connaught in the centuries before A.D. 800 are almost non-existent. ${ }^{17}$ Perhaps they are not meagre or non-existent, just fragmentary and in need of more resourceful handling?

If historians of medieval Ireland are to revisit the parameters of their subject and to initiate fresh approaches, a reorientation in methodology may be required. There will be as many solutions as there are practitioners, but nevertheless a number of options might be considered. Firstly, the creation of more specialist studies or 'micro-studies' are now essential in order to rejuvenate the basis for any future surveys of the period. Such microstudies might tackle specific regions, population groups, dynasties, families or individuals (e.g. why not a biography of Diarmait Mac Murchada?); cover shorter chronological intervals; concentrate on specific topics (e.g. warfare, marriage, property) or on particular types of sources (e.g. charters, as suggested by Frame). Many of these matters have been addressed during the twentieth century, and they have begun to produce spectacular results. ${ }^{18}$ Indeed, the most satisfying papers in the array of material under review are effectively micro-studies which reappraise aspects of medieval Ireland: Marie Therese Flanagan's 'John de Courcy, the first Ulster plantation and Irish church men', ${ }^{19}$ Keith J. Stringer's 'Nobility and identity in medieval Britain and Ireland: the de Vescy family, c. $1120-1314,{ }^{20}$ or Robin Frame's 'King Henry III and Ireland: the shaping of a peripheral lordship'. ${ }^{21}$ At times, however, this approach is not always successful. Richter's

\footnotetext{
${ }^{15}$ Frame, Ireland \& Britain, p. 4: 'Nevertheless, Sweetman's work had what may seem today an important drawback. In the original records the Irish matter lies mingied with all the king's other business, concerning England, Wales and the Angevin lands in France, as well as diplomatic relations with external powers. The act of assembling it under separate covers involved abstracting it from its context.'

${ }^{16}$ Richter, Ireland \& her neighbours, p. 54.

${ }^{17}$ Ó Cróinín, Early medieval Ireland, p. 59.

${ }^{18}$ D. P. McCarthy, 'The chronology of the Irish annals' in R.I.A Proc., xcviii (1998), sect. C, pp 203-55.

${ }^{19}$ Smith (ed.), Britain \& Ireland, pp 154-78.

${ }^{20}$ Ibid., pp 199-239.

${ }^{21}$ Frame, Ireland \& Britain, pp 31-57.
} 
focus on a specific topic, Ireland and her neighbours, during a very specific chronological period, the seventh century, fails to ignite enthusiasm or to portray sufficiently the country which produced and attracted such fervent activity. This may be due to the author's considerable reliance on secondary sources for interpretation of his primary material and the apparently superficial nature of many of his own conclusions regarding primary sources. In this case the book might have been livelier if the author had included some new material or had investigated other aspects in greater detail (e.g. local cults of Irish saints on the Continent).

A second option open to historians is to educate themselves beyond the traditionally influential schools of history, largely those of Ireland and Britain. The considerations and advances of schools of history on the Continent and in the United States should be part of our formation, especially with the increasing availability of material by electronic means. A topic crying out for such a new perspective is that of Ireland's place $v i s-a ̀-v i s$ the Roman Empire, particularly in late antiquity. It seems shameful that no Irish scholar is involved in the large-scale multi-volume project sponsored by the European Science Foundation, 'The transformation of the Roman world', where Irish evidence is crucial. ${ }^{22}$ Does this reflect the consequences of the attitude best expressed by Ó Croinin: 'The less cynical might suggest that early medieval Ireland offers something unique and interesting to the student of history: the record of a people untouched by the civilisation of the Roman Empire. ${ }^{23}$

A third option to allow for the development of a new approach consists of the development of genuine interdisciplinary studies, different from the approach adopted to date. This requires historians and archaeologists, for example, to concentrate on their respective evidence relating to a specific topic, to consider it independently, and when they come to their separate conclusions to begin the process of synthesis. ${ }^{24}$ Archaeological and historical evidence regarding any given topic should not be expected to fit neatly together or even complement each other. The complexity of society probably militates against such perfect solutions, and the divergence between archaeological and historical data undoubtedly reflects that complexity. While archaeologists do not take kindly to historians' admonitions, such as those expressed by Ó Cróinín, ${ }^{25}$ Laurence Flanagan's book Ancient Ireland: life before the Celts illustrates some of the shortcomings of Irish archaeology, especially in prehistory. With origins in a tradition of descriptive catalogues, Irish archaeologists seem to have always found it difficult to interpret and synthesise their material beyond artefactual categories. Whereas the more interpretative philosophy of 'new archaeology' has been introduced in the past decade, the underlying inherent weakness regarding

\footnotetext{
${ }^{22}$ The first volume of this project is Walter Pohl and Helmut Reimitz (eds), Strategies of distinction: the construction of ethnic communities, 300-800 (Leiden, Boston \& Cologne, 1998).

${ }^{23}$ Ó Cróinín, Early medieval Ireland, p. 11.

${ }^{24}$ E.g. Claire Cotter et al., 'Cahercommaun Fort, Co. Clare: a reassessment of its cultural context' in Discovery Programme Reports, no. 5 (1999), pp 41-95.

${ }^{25}$ Ó Cróinín, Early medieval Ireland, pp 9-10.
} 
interpretation remains, as witnessed by the prevalent orthodoxy which seems to classify objects and sites invariably as 'ceremonial', 'ritual' or 'enigmatic'. Such vague terms belie a structural weakness in the subject that of the absence of sufficient training in research methodology. Interdisciplinary work in medieval Irish studies should also involve cooperation with linguists and with anthropologists. There may be a reluctance in the present generation of historians, especially those who were trained in schools of Celtic studies where anthropological parallels inevitably led back to Indo-European prototypes, to engage in this activity. Yet, in instances where our evidence cannot be elucidated any further, anthropological models may be the next step to advance the subject. An obvious example is that of the conversion of Ireland to Christianity, where the immediate sources are confined to Prosper of Aquitaine's reference to Palladius and to Patrick's Confessio and Epistola and where impressions of the process can be gained from the Collectio canones Hibernenses. Whereas anthropology will not provide exact details of what occurred in Ireland from the fourth to the eighth century, its models offer information about stages towards conversion and the motivations that move individuals or communities towards conversion. ${ }^{26}$

Constant themes throughout all the books under review are those everpresent through the twentieth century: the seemingly traditional, unchanging, stable nature of Irish society from prehistory to early medieval history and this enduring idiosyncratic condition continuing into the late middle ages; Ireland's relations with Britain and to a lesser extent with Europe; kingship and lordship; possession and dispossession of land. Perspectives on these themes are often influenced by contemporary thinking, as epitomised by the rationale behind Brendan Smith's volume.

The stable, unique nature of Ireland at the dawn of history is so embedded in the psyche of historians that Richter can proclaim: 'The lack of a Roman phase in Ireland signals also a lack of discontinuity and disruption; instead one has to posit a prehistoric phase which must have been marked by considerable stability; institutions had developed which suited the requirements of Irish society and were maintained because they answered the needs. ${ }^{27}$ This compares with Alfred Smyth's remarkable depiction of Scandinavian society when the Vikings encounter Western medieval Christendom: "The crisis was compounded by the fact that Northmen constituted roving armies of male predators locked into a state of Iron Age cultural regression and operating with a belief system and a set of values appropriate to Celtic or Germanic peoples from a distant pre-Christian past. ${ }^{28}$ It is unlikely that Scandinavian prehistorians researching such highly developed sites as Gamla Uppsala ${ }^{29}$ would recognise these "male

${ }^{26}$ L. J. R. Milis (ed.), The pagan middle ages (Woodbridge, 1998), translated by Tanis Guest from De heidense Middeleeuwen (Brussels \& Rome, 1991).

${ }^{27}$ Richter, Ireland \& her neighbours, p. 18.

${ }^{28}$ Smith (ed.), Britain \& Ireland, p. 25.

${ }^{29}$ Stefan Brink, 'Social order in the early Scandinavian landscape' in Charlotte Fabech and Jytte Ringtved (eds), Settlement and landscape: proceedings of a conference in Århus, Denmark, May 4-7, 1998 (Moesgård, 1999), pp 423-39. 
predators', except perhaps in nineteenth-century depictions. The 'enigma' of Irish prehistory until about the seventh century, as portrayed by Irish archaeology, undoubtedly adds to the impression of a stable, traditional society in Ireland. A greater appreciation of Ireland's role on the edge of Empire, like other regions in Europe and north Africa, and of it as part of a Romano-British world ${ }^{30}$ might unravel this illusory enigmatic Ireland for both archaeologists and historians alike.

The concept of the edge of Empire is an appropriate introduction to the central theme of all the books under review, that of the complex relationship from prehistory to the present day between Ireland and Britain. It dominates discussions in so many aspects, be it Bede's view of the Irish or the ethnic identity of the earls of Desmond, Kildare and Ormond in the fifteenth century. The cultural origins or formation of historians are distinguished by their comments relating to it, wryly proclaimed by John Gillingham in the context of his general belief that Ireland was more violent than elsewhere: 'In an attempt to fight off my natural tendency to a feeling of English superiority, I shall conclude with the strange death of chivalrous England - the reversion to a more brutal political style in the reigns of Edward I and Edward II. ${ }^{31}$ Rather than dwell on the merits or otherwise of certain arguments expounded regarding this complex theme - explored in infinite detail by Frame in his book - I will point to some concepts which seem to merit further detailed exploration. Robert Bartlett concludes his essay 'Cults of Irish, Scottish and Welsh saints in twelfthcentury England' with a very apt consideration of the terminology of barbarism, the idea of the lingua barbara or sermo barbaricus, directed, for example, against Irish sources by hagiographers such as Lawrence of Durham and Jocelin of Furness. ${ }^{32}$ It is ironic that this learned mentality, or perhaps snobbery, finds one of its earliest - and most trenchant - exponents in Adomnán, who opens his Vita Columbae with these harsh words:

Et nec ob aliqua scoticae vilis videlicet ling[u]ae aut humana onomata aut gentium obscura locorumve vocabula, quae ut puto inter alias exterarum gentium diversas vilescunt linguas, utilium et non sine divina opitulatione gestarum dispiciant rerum pronuntiationem. ${ }^{33}$

A study of the concept of barbarism and its related terminology with particular reference to the Irish situation and using the evidence of the related disciplines discussed above might yield results that would ease the burden of Giraldus Cambrensis!

\footnotetext{
${ }^{30}$ On this general topic see Leslie Webster and Michelle Brown (eds), The transformation of the Roman world, A.D. 400-900 (London, 1997).

${ }^{31}$ Smith (ed.), Britain \& Ireland, p. 116.

${ }^{32}$ Ibid., pp 83-6.

${ }^{33}$ Let them not despise the publication of deeds that are profitable, and that have not been accomplished without the help of God, on account of some unfamiliar words of the Irish tongue, a poor language, designations of men, or names of tribes and places; words that, I suppose, are held to be of no value, among other different tongues of foreign peoples' (Adomnán's Life of Columba, ed. and trans. A. O. Anderson and M. O. Anderson (revised ed., Oxford, 1991), pp 2-3).
} 
The 'Celticity' of nations and the concept of Celtic unity is a subject that has been considered by very many scholars, and it continues to rumble on today. ${ }^{34}$ An interesting aspect to this discussion surfaces in the volumes under review, that of the concept of one nation or one people, as understood by the Irish, Scots and Welsh in the medieval period. The concept is discussed in detail by Máire Herbert and Dauvit Broun, ${ }^{35}$ while Seán Duffy emphasises the strength of fellowship that at times may have existed when the Bruce campaign was at its height. Robert Bruce wrote letters to the Irish and to the Welsh in terms of nostra natio. ${ }^{36}$ Almost a century later Owain Glyn Dŵr wrote letters to Irish kings, reminding them of their common kinship, and seeking their assistance against the oppression and tyranny of their common enemy, the Saxons. ${ }^{37}$ At an earlier remove, Duffy also demonstrates how the advance of the Anglo-Normans affected the relationship between Ireland and Wales: 'certain cross-channel links were disrupted, if not ended, but others were greatly reinforced' ${ }^{38}$ Crucial to Richter's interpretation ${ }^{39}$ of the nature of Columba's exile to Iona is how Iona was regarded as part of Ireland or of Britain - possibly a moot point, if I correctly interpret the most recent comments on the matter. ${ }^{40}$ The complexity of cross-cultural relations and the absolute need to reject stereotypes is impressively portrayed by Marie Therese Flanagan when dealing with John de Courcy and Irish church men. ${ }^{41}$ Of the many new details revealed in her essay, the most striking is that of a reform movement divided and of the mutual dependency between certain Irish ecclesiastics and the intruder, de Courcy, each ultimately operating to his own benefit. Why should we (subconsciously at least) continue to believe - or hope that medieval Irish leaders and those they encountered were not as full of wile and intrigue as their present-day counterparts?

The mechanics of cross-cultural influence or integration are identified separately by Ó Cróinín (in the context of the adoption of Christianity) ${ }^{42}$ and in greater detail by R. A. McDonald in his essay 'Coming in from the

\footnotetext{
${ }^{34}$ Patrick Sims-Williams, 'Genetics, linguistics, and prehistory: thinking big and thinking straight' in Antiquity, lxxii (1998), pp 505-27.

${ }^{35}$ Smith (ed.), Britain \& Ireland, pp 87-97, 135-53. Máire Herbert continues to deal with this theme in 'Rí Éirenn, rí Alban, kingship and identity in the ninth and tenth centuries' in Simon Taylor (ed.), Kings, clerics and chronicles in Scotland, 500-1297: essays in honour of Marjorie Ogilvie Anderson on the occasion of her ninetieth birthday (Dublin, 2000), pp 62-72.

${ }^{36}$ Duffy, Ireland in the middle ages, $\mathrm{pp} 135-6$.

${ }^{37}$ These matters have been discussed in detail in R. R. Davies (ed.), The British Isles, 1100-1500: comparisons, contrasts and connections (Edinburgh, 1988); idem, Domination and conquest: the experience of Ireland, Scotland and Wales, 1100-1300 (Cambridge, 1990).

${ }^{38}$ Smith (ed.), Britain \& Ireland,p. 112.

${ }^{39}$ Richter, Ireland \& her neighbours, pp 48-53.

${ }^{40}$ Richard Sharpe, 'The thriving of Dalriada' in Taylor (ed.), Kings, clerics \& chronicles, pp 47-61.

${ }^{4}$ Smith (ed.), Britain \& Ireland, pp 154-78.

${ }^{42}$ Ó Cróinín, Early medieval Ireland, pp 36-40.
} 
margins: the descendants of Somerled and cultural accommodation in the Hebrides, 1164-1317'.43 Apart from addressing the age-old theme of the relationship between the core and the periphery (which appears so frequently in Frame's book), McDonald attempts to identify indicators of integration, among them personal names, marriage alliances, the adoption of the culture of knighthood such as issuing charters, use of seals or changes in titles. The idea of changing titles introduces another pervading theme, that of kingship and lordship, so dominant that it occurs in most major twentieth-century works relating to medieval Ireland. Despite this, the subject still has much information to yield. The idea, for example, that cultural or political transformation is reflected in the adoption of new titles or in the modification of the old emerges occasionally, as in Ó Cróinín's question whether Anglo-Saxon aetheling preceded Old Irish rigdomna, and might it have suggested the concept to the Irish. 'The evidence as it stands, unfortunately, does not allow a categorical answer to this question. ${ }^{44}$ The context of this very valid question, however, may not be confined to Ireland or Anglo-Saxon England but may form part of the circulation of ideas between early medieval barbarian successor states. ${ }^{45}$ The confirmation of authority, be it from within a given society or externally, is also linked to title. Witness the case of Toirrdelbach Ó Briain, who had been confirmed as chief of his name by the justiciar, William of Windsor, elevating him, according to Toirrdelbach in a submission dated 1378 , per regalem potenciam thus acknowledging a validation of authority by the English crown. However, the justiciar's withdrawal from Munster meant that Toirrdelbach's predecessor, consistently described by him as antiquus OBreen, had resurfaced to reassert his claim to the chiefdom. ${ }^{46}$ This is a stark depiction of the tension between new and old conventions which must have been repeated on hundreds (if not more) occasions throughout the medieval period and which have yet to be fully uncovered. Tension between new and old, those in the ascendant and those in decline, not only manifested itself in changes of titles or mores, but also in the much more traumatic possession and dispossession of land. What exactly happened in the sixth/seventh or in the twelfth/thirteenth centuries when there was a considerable upheaval, at least among those who were in power? Ideas about people being banished to badlands or to the margins seem to suffice as an explanation for the mechanics of intrusion and dominance. This is hardly adequate as a theory for situations which must have varied from region to region and from decade to decade. This theme of the process of possession and dispossession of land seems ripe for a 'micro-study', although it would necessarily be a weighty study, given all its manifestations and implications.

Eoin MacNeill in Celtic Ireland and Dáibhí Ó Cróinín in Early medieval Ireland, 400-1200 rightly lamented the fact that so few students progressed

${ }^{43}$ Smith (ed.), Britain \& Ireland, pp 179-98.

${ }^{4}$ Ó Cróinín, Early medieval Ireland, p. 69.

${ }^{45}$ Hervig Wolfram, 'Origo et religio: ethnic traditions and literature in early medieval texts' in Early Medieval Europe, iii, 1 (1994), pp 19-38.

${ }^{46}$ Frame, Ireland \& Britain, pp 266-7. 
to research in a field in which so much work remained to be done. Plus ça change. While agreeing with their sentiments, perhaps we should adopt a more optimistic view and decide as an academic community charged with the education of a new generation of scholars to identify the few who are interested from their undergraduate years and to nurture them by providing them with as rounded an education as possible and with every opportunity that can be created for them. Allow them to experience the wider world of scholarship and, in the meantime, create high-quality schools of research for them to which they can return to contribute to medieval studies in Ireland.

EDEL BHREATHNACH Department of Old Irish, National University of Ireland, Galway 